\title{
REPORT OF THE TREASURER FOR THE YEAR 1920
}

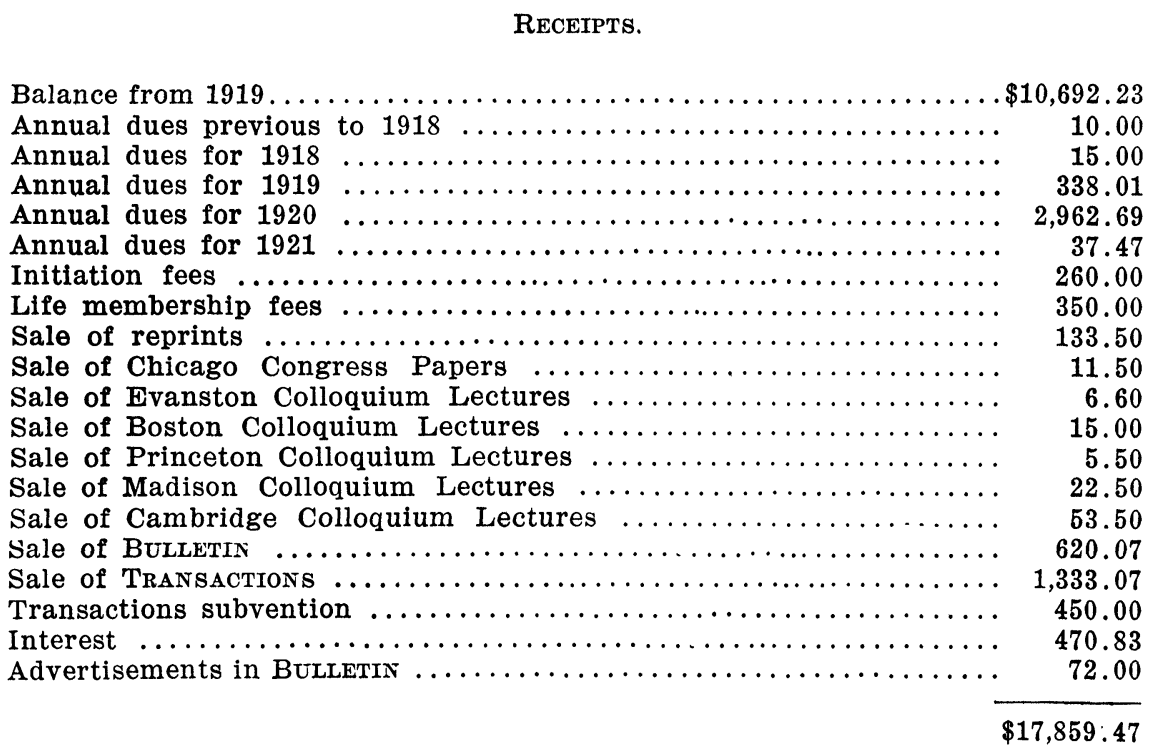

Disbursements.

Secretary's Office $\ldots \ldots \ldots \ldots \ldots \ldots \ldots \ldots \ldots \ldots \ldots \ldots \ldots \ldots \ldots \ldots \ldots \ldots 78.99$

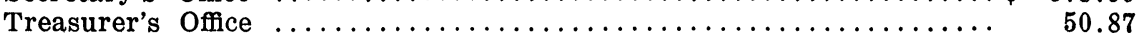

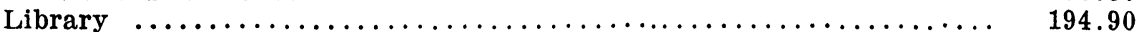

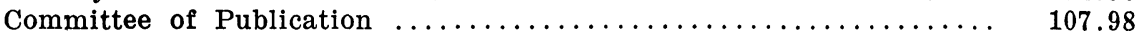

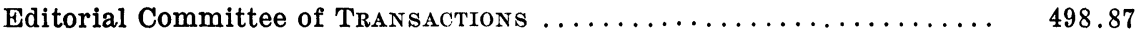

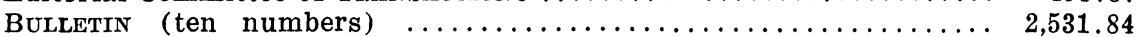

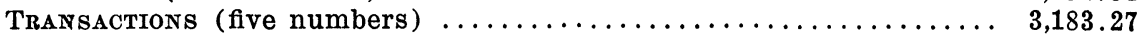

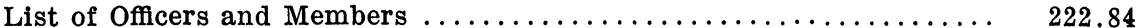

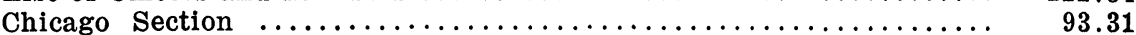

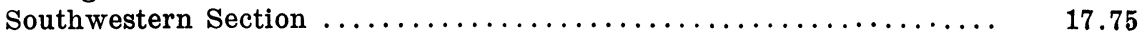

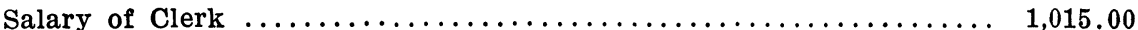

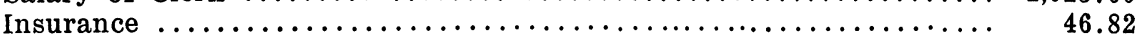

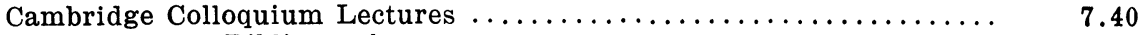

Committee on Bibliography $\ldots \ldots \ldots \ldots \ldots \ldots \ldots \ldots \ldots \ldots \ldots \ldots \ldots \ldots$

$\$ 8,864.94$ 
Investments (par value $\$ 8,500.00) \ldots \ldots \ldots \ldots \ldots \ldots \ldots \ldots 8,259.50$

Balance in First National Bank (Ithaca), less outstanding

check, $\$ 85.00 \ldots \ldots \ldots \ldots \ldots \ldots \ldots \ldots \ldots \ldots \ldots \ldots \ldots \ldots \ldots 735.03 \quad 8,994.53$

$\$ 17,859.47$

The Life Membership Fund now amounts to $\$ 7,814.79$.

J. H. TANNER,

Treasurer.

ITHACA, N. Y.,

December 21, 1920.

\section{REPORT OF THE AUDITING COMMITTEE}

The undersigned Auditing Committee, appointed by the American Mathematical Society, have this day examined the accounts of the Treasurer, compared them with the vouchers, the certified bank statement of the bank balance, and the certified statement of the Treasurer of Cornell University, that the securities and mortgages owned by the Society are in the hands of the Treasurer of the Society, and find the following to be correct:

Balance from December $23,1919 \ldots \ldots \ldots \ldots \ldots \ldots \ldots \ldots \ldots \ldots \ldots \ldots 10,692.23$

Cash receipts since December $23,1919 \ldots \ldots \ldots \ldots \ldots \ldots \ldots \ldots \ldots \ldots, 167,24$

$\$ 17,859.47$

Balance in First National Bank (Ithaca) less outstand-

ing check ........................... \$735.03

Investments (par value $\$ 8,500.00) \ldots \ldots \ldots \ldots \ldots \ldots \ldots \ldots 8,259.50$

Disbursements since December $23,1919 \ldots \ldots \ldots \ldots \ldots \ldots \ldots 8,864.94$

$\$ 17,859.47$

Paul Saurel,

W. B. FITE,

NEw YoRK, N. Y.,

Auditing Committee.

December 21, 1920. 